\title{
Boots on the ground in Africa's ancient DNA 'revolution': archaeological perspectives on ethics and best practices
}

\author{
Mary E. Prendergast ${ }^{1, *} \&$ Elizabeth Sawchuk ${ }^{2, *}$
}

Recent methodological advances have increased the pace and scale of African ancient DNA (aDNA) research, inciting a rush to sample broadly from museum collections, and raising ethical concerns over the destruction of human remains. In the absence of discipline-wide protocols, teams are often left to navigate aDNA sampling on an individual basis, contributing to widely varying practices that do not always protect the long-term integrity of collections. As those on the frontline, archaeologists and curators must create and adhere to best practices. We review ethical issues particular to African aDNA contexts and suggest protocols with the aim of initiating public discussion.

Keywords: Sub-Saharan Africa, archaeogenetics, human remains, destructive analysis, museum studies

\section{Introduction}

In recent years, the pace of human ancient DNA (aDNA) research in Africa has accelerated, from studies of single individuals to analyses of larger groups with wider analytical scope (Morris et al. 2014; Gallego Llorente et al. 2015; Rodríguez-Varela et al. 2017; Schlebusch et al. 2017; Schuenemann et al. 2017; Skoglund et al. 2017). Human aDNA from African contexts is globally exceptional in that it holds the potential to address deep-time questions on our species' origins. As on other continents, aDNA can also illuminate recent biological adaptations, and can be analysed alongside archaeological and linguistic evidence to examine, for example, changing population dynamics associated with the spread of food production or with trade networks. Until recently, such questions have focused on Eurasian contexts.

Archaeogenetics in Africa—a continent previously ignored by the 'Genomics Revolution' in living populations (Nordling 2017) — has been slow to develop, due in part to notoriously poor aDNA preservation in warm, tropical climates. Recent achievements have been fuelled

\footnotetext{
Department of Sociology \& Anthropology, Saint Louis University, Avenida del Valle 34, 28003 Madrid, Spain

2 Department of Anthropology, Stony Brook University, Circle Road, SBS Building S-501, Stony Brook, NY 11794-4364, USA

* Authors for correspondence (Email: mprendergast@post.harvard.edu; esawchuk@gmail.com)
}

(C) Antiquity Publications Ltd, 2018. This is an Open Access article, distributed under the terms of the Creative Commons Attribution licence (http://creativecommons.org/licenses/by/4.0/), which permits unrestricted reuse, distribution and reproduction in any medium, provided the original work is properly cited. 
by cheaper sequencing, more efficient DNA-extraction and -preparation techniques, and new enrichment methods that restrict analysis to informative parts of the genome (Meyer \& Kircher 2010; Meyer et al. 2012; Dabney et al. 2013; Fu et al. 2013, 2015). The bestknown discovery, however, is that the petrous portion of the human temporal bone (often called the petrous pyramid) is richer in endogenous aDNA than any other skeletal element, and can yield sequences from poorly preserved material (Pinhasi et al. 2015). Humans possess two petrous pyramids - one on each side of the skull — that house the inner ear structures and reinforce the cranial base. The petrous region contains some of the densest bone in the body, and thus often preserves well archaeologically.

Although new techniques minimise the amount of petrous pyramid used in aDNA analyses (Sirak et al. 2017), human remains are a non-renewable, yet intensively sought, resource. This raises concerns about the sustainability and ethics of current practices (Makarewicz et al. 2017). In the absence of discipline-wide protocols, individual research teams are often left to navigate sampling on a case-by-case basis, thereby contributing to widely varying and minimally documented practices. Archaeologists and curators are the 'boots on the ground' in this aDNA revolution, as they work with collections and ultimately make the most difficult decision of all: when is it acceptable to destroy human remains? Here we examine this question, alongside ethical issues particularly relating to African biomolecular research, with the goal of creating a more formal and public dialogue than the private discussions currently taking place via emails and across dining tables. While documents such as the Vermillion Accord (WAC 1989) outline the ethical treatment of human remains, tailoring these ideals to diverse research contexts is complex. Regional and indigenous-driven policies, such as the San Code of Ethics (SASI 2017), are still rare and call for respect from genomics researchers without providing specific directives. A new code of ethics for African genomics research (Yakubu et al. 2018) addresses many of the concerns we raise here, but applies to modern samples. Such documents rarely address destruction of ancient human tissue, nor how ethical principles, such as respect and care, translate into archaeological sampling protocols.

In this paper, while recognising that ethics are subjective, we focus on three core issues within aDNA research: the dignified treatment of human remains; respect for and protection of cultural heritage; and the long-term preservation of future research opportunities. We outline a specific set of suggested protocols, drawing upon our experience in an ongoing project that examines ancient population structures and dynamics during the spread of food production in Holocene Africa. Since 2016, we have written seven proposals to sample African archaeological skeletons curated at African, European and North American institutions, and we have worked intensively in three African national museums to make inventories of human remains and choose samples for aDNA analysis. We reflect upon lessons learned and suggest best practices to develop, execute and follow through on collaborations focused on aDNA; many of these may be extended to other destructive analyses. We aim to stimulate exchanges amongst multiple stakeholders: not only curators, archaeologists and geneticists, but also descendant communities and the broader public, who do not always have a voice in the scramble for African human remains. Ultimately, we hope such discussion will lead to the development of a professional code of ethics for African aDNA research.

(C) Antiquity Publications Ltd, 2018 


\section{Mapping uncharted territory: the true revolution}

While aDNA is frequently hailed as revolutionary, many of the questions that genetics can address have been explored for decades using archaeological, bioarchaeological and linguistic data-albeit at varying spatial and temporal scales of analysis (De Luna et al. 2012; Robertshaw 2012; MacEachern 2013). The true revolution is in our practice: archaeogenetics thrusts together specialists who not only have different training, but also distinct work cultures (Pluciennik 2006). Morris's (2017: 2) commentary on the "teenage problems" of African archaeogenetics cites competition among laboratories "chasing the next Nature paper" - an issue tied to funding and promotions. While this situation is certainly not alien to archaeologists, the levels of funding, pace of publication and target journals and audiences are often distinct. Geneticists are also less likely to leave the laboratory to obtain samples, underscoring a perceived disconnect from archaeologists, curators and descendants in the source countries. Geneticists may be well acquainted with the science, but not the location-specific politics of obtaining samples; for archaeologists, the opposite is often true.

Rather than depicting the laboratory-bound geneticist as a bogeyman, however, we should refocus efforts on creating genuine collaborations based on equal footing. Our field's history—in particular the Radiocarbon Revolution-testifies to our ability to find common ground amongst archaeologists and scientific specialists (Pollard \& Bray 2007). For aDNA, we sense that many Africanist archaeologists find themselves either caught within a fastpaced competition, or watching it from the sidelines. As scholars with deep knowledge of specific regions and with local contacts, many of us have been asked to collect samples during our own research, or to facilitate relationships between African museums and foreign laboratories. Rather than feeling adrift, or turning our backs on aDNA altogether, we must work to make these projects driven by archaeologists and curators. We must also grapple with ethical concerns raised elsewhere with respect to biomolecular studies, such as the destruction of human remains and questions of consent (e.g. Kaestle \& Horsburgh 2002), as they pertain to African contexts. Although we speak from the Africanist perspective, many of the ethical issues raised are likely to apply to other post-colonial contexts. Regional dialogues on aDNA work may ultimately stimulate broader anthropological discussions regarding the treatment of archaeological human remains.

\section{Colonial legacies and ethical considerations in African archaeogenetics}

Africa's past makes the continent highly attractive to geneticists: sub-Saharan Africa boasts the greatest genetic diversity on the planet, and its centrality in human origins makes both modern and ancient genetic research especially illuminating. African aDNA studies are high-impact publications, thus raising the stakes of the research. Simultaneously, Africa's underfunded archaeological research history-particularly for the Holocene-means that there are fewer skeletons available for study than elsewhere. As sample sizes are miniscule for the geographic and chronological expanses involved, each archaeological individual is even more precious. Discovery of the petrous pyramid's potential and the ability to extract 
aDNA from increasingly early skeletons may have helped spur the current race to sample widely in museums - at a pace exacerbated by inter-laboratory competition. An analogy to the Scramble for Africa is regrettably apt, and makes it particularly important to consider how Africa's colonial history affects multiple aspects of research on human remains.

Recent calls have been made for ethical and regulated archaeogenetic research, in an age in which a few laboratories dominate access to samples worldwide (Makarewicz et al. 2017). While the Nagoya Protocol (CBD 2011) provides guidelines for fair access to samples and data, this was written with modern genetic resources in mind; additional consideration must be given to archaeogenetic samples. Morris (2017) identifies pertinent issues in Africa and beyond, including competition without question-driven research; 'parachute' research, where samples are taken out of the country without engaging in long-term collaborations and capacity-building; geneticists' ignorance (or dismissal) of bioarchaeological evidence; and lack of data comparability due to differing sample-processing methods among laboratories. Here, we highlight additional concerns that intertwine with Africa's colonial history, and which are relevant to destructive analyses beyond aDNA.

\section{Who 'owns' human remains? Who gives sampling permission?}

Colonial legacies become apparent in any search for African human skeletal collections. As these are often fragmented across continents, the logical cultural, chronological or geographic groupings of sites are torn apart, as are populations of individuals within sites, and even individual skeletons - depending on when and by whom they were excavated. A colonial-era penchant for exporting archaeological skulls, for example (see Hrdlicka 1918), led to the isolation of many individuals' heads from their bodies, an issue that remains largely unaddressed. While there have been efforts, led by African and European civic groups and governments, and by intergovernmental organisations (such as the UN) to repatriate historical human remains, for example from Germany to Namibia, and from Spain to Botswana (Parsons \& Segobye 2002; Wittwer-Backofen et al. 2014), public calls for repatriation of archaeological skeletons are rare (e.g. Musonda 2013). This issue is not limited to European and North American institutions. Within Africa, skeletal collections were moved widely across colonies controlled by a single power, leading to fragmentation across post-colonial states. Additionally, material often travelled to nearby countries where relevant expertise or facilities could be found, leading to the long-term curation of human remains outside their country of origin (e.g. Steyn et al. 2013).

While repatriation is complex, determining who grants access to collections may be even more so. Permission to access foreign-held human remains should come from both the holding institution and the appropriate public body (and possibly other stakeholders) in the country of origin. In our experience, however, it is rare to require African governmental permission to sample in non-African institutions. Conversely, even if access is granted by the country of origin, it may be denied by the foreign institution based upon their own internal criteria.

African stakeholders are themselves heterogeneous in that they include not only researchers, curators and government entities, but also communities who consider themselves descendants or guardians of human remains. These are by no means (C) Antiquity Publications Ltd, 2018 
homogeneous groups, and notions of descent and ownership may be contested within and among communities. Stakeholders may therefore hold conflicting views on enabling or denying access to human remains, whether these are curated outside or within the country of origin, or are under excavation. Furthermore, the issue of access may raise tensions between actors with relative power (e.g. museums and government bodies) and those without. Decolonising archaeological practice in Africa (see Schmidt \& Pikirayi 2016) necessitates engaging with local communities during the excavation of human remains. It may also mean obtaining permission for post-excavation analyses from these communities, and not solely from government authorities. Straight et al. (2015) offer an example of this practice, but such bottom-up approaches remain rare in Africa.

\section{How do colonial legacies affect sampling and data-management practices?}

What does the colonial legacy mean in pragmatic terms? Seemingly simple actions, such as exporting human bone to a foreign genetics laboratory because it has appropriate cleanroom facilities, parallel historical justifications for exporting African cultural heritage to better-funded foreign museums. While there are currently no designated aDNA laboratories on the continent, plans for sample exportation and repatriation must be discussed upfront and explicitly with African curators, with every effort made to involve museums or other institutional scientists as partners. aDNA research produces several types of archives: physical sample remainders (bone and/or powder), which can be easily repatriated; derived molecular products (DNA extracts and libraries), which require strict temperature and contamination controls, and are typically curated long term in the laboratory; and genetic sequences themselves, which must be published. Each of these archives requires a plan, in agreement with curators, for repatriation and/or long-term curation, publication and access by future researchers if archives are curated outside the country of origin.

Colonial legacies can also lead to the interpretation of common collegial practices in archaeology as neo-colonial gestures. For example, we contacted dozens of non-African scholars who excavated African human remains that we wished to sample-not to ask their permission, but rather to enlist help obtaining unpublished contextual information and interpreting results. In retrospect, this may have been perceived as foreign archaeologists negotiating amongst themselves to decide upon African cultural heritage.

aDNA sampling is new to many curating institutions within and beyond Africa. In many African countries, existing destructive analysis policies (focused on radiocarbon dating and/or stable isotope analysis) must be revisited to consider the requirements of genetic research. Data-management plans must address the need for curating institutions to control information about their collections, while making genetic sequences publicly available so that other researchers can form independent opinions about scientific claims, and as a condition for scientifically ethical publication. In our experience, African institutions may view publicly accessible genetic databases sceptically. This is understandable given past exploitation of African biological data for foreign gain - in colonial medical research, for example (Tilley 2016) — and recent bioethical discussions on modern DNA sampling (e.g. Wright et al. 2013). 


\section{Where, how and by whom should aDNA results be presented and interpreted?}

The colonial legacy must be considered throughout interpretation and publication. Target journals for most aDNA papers are based in Europe or North America, and author lists are weighted heavily towards specialists from these regions. Future publications must be collaborative with African scholars and heritage managers, and made open access. Results should be made available not only through scientific journals, but also through multiple lines of dissemination to non-specialists. This might include materials designed specifically for students, educators, descendant or guardian communities, and the broader public in the countries where research takes place (written in appropriate languages).

We must collectively consider how research results will be presented to, received within and mobilised by public audiences-including descendants for whom the line between archaeological and modern human remains may be indistinct. Unlike North America and Oceania, where legislation has generated decades of debate on ownership, repatriation and reburial, parallel public discussions have not happened in much of Africa, with the important exception of South Africa (Nienaber \& Steyn 2011; Morris 2014).

Potential outcomes of African aDNA research may include new efforts to define descendant groups, activism for repatriation and reburial, and political engagement with narratives - often based upon oral tradition — of migration and ethnic origins. These discussions will likely involve arguments concerning ties among genes, language and contemporary identities, concepts that have often been treated in reductionist ways in the history of African anthropology and archaeology (MacEachern 2000). A well-known example of this is the conflation and abuse of linguistic, archaeological and biological data to support the Hamitic Myth. This myth holds that descendants of the biblical figure Ham migrated into North-eastern Africa and were responsible for the continent's cultural and technological development (Seligman 1930; critical discussion by Sanders 1969). These fallacies have serious implications, particularly where land disputes are tied to notions of identity. An especially devastating example was the invocation of the Hamitic myth to justify violence in the Rwandan genocide (Eller 1999). While archaeologists cannot offer specific 'answers' to complex arguments surrounding genetic, linguistic and cultural identities, we contribute to the tone of discussion, and we shape the quality of evidence on which debates rest.

\section{Best practices for aDNA research in institutional collections}

Stakeholders involved in aDNA research include museum or other institutional curators, archaeologists, geneticists and heterogeneous public audiences. There may be yet other voices shaping the research process, including university employers, funding bodies, journals, professional associations and government agencies. Stakeholders are concerned not only about the destruction of cultural heritage in pursuit of new research, but also about how sampling will reflect upon themselves or their institution. Most also appreciate the potential for exploration made possible only through destructive methods. How do we balance the cost of destroying human remains with the benefit to scientific discovery? To return to our central question, when is it acceptable to destroy human remains?

(C) Antiquity Publications Ltd, 2018 
Not all African curatorial institutions and governments currently have policies and boards that provide oversight on this question, although aDNA research may catalyse their development. For now, researchers must employ best practices analogous to those developed elsewhere, which may ultimately become formalised as policy. A central issue concerns the selection of samples. For field excavations of human remains where goals include aDNA analysis (e.g. Matisoo-Smith \& Horsburgh 2012; Allentoft 2013), best practices focus on how to identify and handle elements with probable aDNA preservation over considerations of which elements may be valuable in future research. Osteological manuals only state requirements for documentation and osteobiographical analyses prior to sample destruction (e.g. Buikstra \& Ubelaker 1994; APABE 2013; Antoine \& Ambers 2015; Mitchell \& Brickley 2017). Furthermore, such handbooks are biased towards European and North American contexts and may not apply well to the politics of African collections. Existing bioarchaeological standards emphasise how to collect biomolecular samples during excavation and museum study, as opposed to indicating what samples can be justifiably used for this purpose. Ultimately, this leads to scenarios in which, even where institutional or higher approval is required, the choice of which tissue to destroy is left to those on the frontlines: archaeologists and especially bioarchaeologists tasked with selecting samples. Walking this line necessitates decisions on a case-by-case basis for each individual skeleton.

It is impossible to create a universal set of rules that will apply to all collections. Our experiences working with multiple institutions and numerous archaeological contexts, however, suggest that some protocols should almost always be followed. Fundamentally, as little bone as possible should be taken and in such a way as to preserve multiple avenues of future research. Collection should follow strict anti-contamination protocols to ensure that processed samples have the best chance of success. Finally, research proposals should include an explicit discussion of who owns the products of research, who will be involved in interpretation and how and when material will be returned to the source country. Here we suggest some best practices to develop a programme that maximises success—both in terms of scientific outcome and collaborative engagement-while minimising loss to collections (see also Table 1).

\section{Getting started: developing a research project}

1. Researchers must identify and listen to key stakeholders, being specific about project goals, and explicit about proposed sample destruction.

2. Country- and institution-specific research and export requirements must be determined, and budgets must account not only for sampling, but also for sample return and continued engagement with collaborating institutions.

3. Archaeologists should not feel bound to any single laboratory or researcher, but rather choose appropriate laboratories and techniques based on research questions. Curating institutions should be provided with proof of the laboratory's history of success, for example, by sharing results from prior studies, or by conducting a pilot study.

4. It is imperative to avoid a 'sample first, ask questions later' approach. An ethical approach identifies specific sites, contexts and individuals required to meet defined scientific goals. 
Table 1. Best practices for destructive sampling of archaeological human remains.

\begin{tabular}{|c|c|}
\hline Goal & Best practices \\
\hline $\begin{array}{l}\text { Minimise } \\
\text { contamination }\end{array}$ & $\begin{array}{l}\text { - Wear gloves and change them frequently. } \\
\text { - Avoid touching hair, skin and surfaces. } \\
\text { - Handle specimens as little as possible. } \\
\text { - Use individual sterile foils to weigh/photograph each specimen. } \\
\text { - Use sterile bags and avoid re-opening. } \\
\text { - When drilling, use protective equipment (goggles, mask, gloves) and tool } \\
\text { sterilisation protocols. } \\
\text { - Store samples in a cool, dry, secure place. }\end{array}$ \\
\hline $\begin{array}{l}\text { Document all steps } \\
\text { of sampling }\end{array}$ & $\begin{array}{l}\text { - Leave clearly written tags on acid-free paper in bags and/or trays from } \\
\text { which samples are taken. } \\
\text { - Tags should minimally include: site, accession number, relevant catalogue } \\
\text { and/or context codes, project-specific sample number, skeletal element, } \\
\text { date removed and contact person for follow-up questions. } \\
\text { - Tags should be updated upon sample return but left in tray. } \\
\text { - Photograph each specimen from several perspectives. } \\
\text { - If drilling, take before and after photographs. } \\
\text { - Create a digital database of all samples. } \\
\text { - Deposit a copy of database and photographs with the curating institution. } \\
\text { This should be maintained, even after the specimens are returned. }\end{array}$ \\
\hline $\begin{array}{l}\text { Minimise impacts } \\
\text { on future } \\
\text { bioarchaeological } \\
\text { research }\end{array}$ & $\begin{array}{l}\text { For teeth: } \\
\text { - Choose isolated teeth, not those still within jaws. } \\
\text { - Choose teeth with broken crowns and/or that have an unbroken antimere } \\
\text { (opposite-side pair). } \\
\text { - Avoid teeth with significant dental calculus residues. } \\
\text { - Avoid teeth affected by dental disease. } \\
\text { - Avoid teeth with rare morphologies, e.g. peg teeth. } \\
\text { - Avoid teeth in the process of eruption. } \\
\text { For temporal bones/petrous pyramids: } \\
\text { - Choose isolated petrous pyramids instead of those attached (naturally or } \\
\text { through reconstruction) to the skull. } \\
\text { - When a cranium is intact, consult the museum on the possibility of } \\
\text { cranial base drilling (Sirak et al. } 2017 \text { ). This should only be done if the } \\
\text { specimen is well preserved and highly relevant to research questions. } \\
\text { - Select petrous pyramids for which an antimere is present, whenever } \\
\text { possible. } \\
\text { - If a site has many individuals with isolated petrous pyramids, choose a } \\
\text { subset (e.g. only left or only right), to prevent double-sampling } \\
\text { individuals, and to leave unsampled individuals for future research. } \\
\text { For other types of bone: } \\
\text { - Choose small, morphologically uninformative bone (e.g. a limb shaft } \\
\text { fragment) with no articular areas. } \\
\text { - If morphologically informative, then choose bones with an antimere or } \\
\text { other morphologically similar elements present (phalanges, for example). } \\
\text { - Avoid pathologically altered bone, unless relevant to research. } \\
\text { - Avoid elements informative about age, sex, or life history (e.g. bones in } \\
\text { the process of fusing, erupting teeth, diagnostic pelvic features). }\end{array}$ \\
\hline
\end{tabular}


5. It may be helpful to contact the excavators of targeted skeletons to obtain critical contextual or preservation information unavailable in publications or accession registers.

6. Sampling teams must include appropriate specialists, ideally a bioarchaeologist or osteologist and somebody trained in aDNA sampling techniques (Sirak et al. 2017). Museum collaborators should contribute intellectually to project development and the interpretation of results, and not be offered co-authorship on publications solely in exchange for access to samples.

7. All parties should agree to terms of collaboration, ideally through a memorandum of understanding (MOU) between/among institutions, rather than individuals. This document, as well as research proposals and permit applications, must be explicit about methods, and must outline plans for sample export, return and archiving. The MOU should also identify which institutions maintain intellectual property rights, specifying who can access archives, and what permissions are needed for future research employing them.

\section{Selection and documentation of tissue samples from collections}

1. Sampling teams must establish protocols to minimise contamination at all stages of collection, and to document fully sampling procedures, for the benefit of curating institutions and future researchers.

2. Researchers should minimise impacts on future bioarchaeological research by choosing samples that are less informative about the individual's age, sex, disease or life history. Whenever possible, researchers should also add value to collections by recording an individual's osteobiographical details, as well as conservation notes. This information should be deposited with the institution.

3. No more than two tissue samples per individual should be collected without consultation with curators and reasonable justification tied to research questions. Second samples should be taken only as backup for aDNA or dating, in the event that the first sample is unsuccessful—and will often be returned intact, if not used.

\section{Research does not end in the laboratory: following through on collaborations}

1. Researchers must adhere to plans for sample return and archiving within the minimum time necessary to ensure quality research. As a general guideline, samples should not be kept beyond a year without justification and permission. Collaborators should be informed of laboratory progress, with reports submitted to curating institutions and appropriate government bodies.

2. When samples are returned, electronic and paper documentation should be updated accordingly.

3. Institutional collaborators should be involved in the interpretation and co-publication of results; this may require in-person follow-up meetings.

4. Researchers should reach beyond the scientific community to communicate findings to public audiences; for example, in pamphlet or poster format, or through local presentations. 
5. Researchers should strive to maintain long-term ties with collaborators and colleagues, and to build capacities by developing new research projects, mentoring and co-writing communications that build upon the initial results.

\section{Discussion: the future of the African aDNA 'revolution'}

Ethical aDNA research starts with adherence to a commonly agreed upon set of best practices that respect the sensitive history of African human remains, facilitate meaningful collaborations among laboratories, archaeologists and curators, and guide responsible sampling. It takes time to build relationships and to make deliberate, conservative sampling decisions. Time, in fact, is a key point of tension regarding current sampling practices, which seem to be driven largely by competition among laboratories. Only archaeologistand curator-driven approaches - grounded in and limited by specific research questionscan change this situation and build a more sustainable and ethical future for African aDNA research. By calling for discipline-wide guidelines, we do not intend to create barriers to research or scare away those interested in archaeogenetic questions. Rather, we hope to stimulate a research-positive environment committed to open scholarship and scientific rigour, which also incorporates anthropological values and paves the way for long-term research and engagement.

Many open questions remain. Which professional bodies and public institutions, in and outside of Africa, will design and enforce codes of ethics? Can existing bioethical codes be expanded to include archaeogenetic research, and how are the issues distinct (or not) from those of sampling modern DNA from living people? Which stakeholders must be consulted for permission to conduct destructive research on human remains? Straight et al. (2015) collaborated with Samburu community members in the excavation of burial cairns in Kenya and received permission based on informed consent for destructive scientific analyses (P. Lane pers. comm.). While this may be a good model for future excavations (notwithstanding the problems of defining descendant or guardian communities), granting or denying access to museum collections is arguably a more complex matter. How should public engagement be led by curating institutions, especially when the collections in question have been held for decades or centuries? Are there certain types of collections that should never be analysedthose younger than a certain age, for example? And if so, where is the line between 'archaeological' and 'modern'? Given that in much of modern Africa, Muslim burials are left unexcavated out of respect for tradition, should analyses therefore proceed on museum collections with Islamic origins?

Perhaps the most challenging questions will arise with public reception of aDNA results. Political manipulation of archaeological data has long been an issue throughout the field (e.g. Trigger 2006), but genetic data are perhaps particularly sensitive to such exploitation. Current debates in the Indian press, for example, contrast new archaeogenetic findings with old narratives about Aryan origins (Joseph 2017). The tone in some articles demonstrates how quickly research can be contested and abused for political aims. In a few clicks, one can easily find racist and pseudoscientific online discussions of legitimate genetic studies, including African ones. We must all strive for public debates to remain rooted in truth.

Big-picture ethical questions must start with well-grounded foundations, and a common framework for destructive human remains sampling represents a good start. Finding a better (C) Antiquity Publications Ltd, 2018 
way forward requires more dialogue and debate among those invested in Africanist research. Given Africa's colonial and post-colonial history, it is surprising that archaeological ethics are so rarely debated_-as observed in a recent special issue on this topic (Giblin et al. 2014). In today's climate of fast-paced research, such debate is urgent.

\section{Acknowledgements}

Sawchuk and Prendergast contributed equally to this paper, and are joint first authors. We thank Susan Pfeiffer, Alan Morris, Scott MacEachern and David Reich, whose comments improved earlier drafts of this manuscript, and the three anonymous reviewers whose thoughtful feedback further enhanced the paper. We gratefully acknowledge Fredrick Manthi, Emmanuel Ndiema, Christine Ogola, Audax Mabulla, Agness Gidna, Maggie Katongo, Jonas Oppenheimer and David Reich for their contributions to related research and discussions that stimulated the creation of this paper. All errors or omissions are our own. Funding for open-access publication was generously provided by Saint Louis University-Madrid.

\section{References}

Allentoft, M.E. 2013. Recovering samples for ancient DNA research-guidelines for the field archaeologist. Antiquity Project Gallery 87(338). Available at:

https://www.antiquity.ac.uk/projgall/allentoft338/ (accessed 17 May 2018).

Antoine, D. \& J. Ambers. 2015. The scientific analysis of human remains from the British Museum Collection: research potential and examples from the Nile Valley, in A. Fletcher, D. Antoine \& J.D. Hill (ed.) Regarding the dead: 20-30. London: British Museum.

APABE (Advisory Panel on the Archaeology of Burials in England). 2013. Science and the dead: a guideline for the destructive sampling of archaeological human remains for scientific analysis. Swindon: English Heritage.

Buikstra, J.E. \& D.H. Ubelaker (ed.). 1994. Standards for data collection from human skeletal remains (Arkansas Archeological Survey Research Series 44). Fayetteville: Arkansas Archeological Survey Research Series.

CBD (Convention on Biological Diversity). 2011. Nagoya protocol on access to genetic resources and the fair and equitable sharing of benefits arising from their utilization to the Convention on Biological Diversity. Quebec: Secretariat of the Convention on Biological Diversity. Available at: https://www.cbd.int/abs/doc/protocol/nagoyaprotocol-en.pdf (accessed 17 May 2018).

Dabney, J., M. Knapp, I. Glocke, M.-T. Gansauge, A. Weihmann, B. Nickel, C. Valdiosera, N. Garcia, S. PäÄbo, J.-L. Arsuaga \& M. Meyer. 2013. Complete mitochondrial genome sequence of a Middle Pleistocene cave bear reconstructed from ultrashort DNA fragment. Proceedings of the National Academy of Sciences of the USA 110: 15758-63.

https://doi.org/10.1073/pnas.1314445110
De Luna, K.M., J.B. Fleisher \& S.K. McIntosh. 2012. Thinking across the African past: interdisciplinarity and early history. African Archaeological Review 29: 75-94. https://doi.org/10.1007/s10437-012-9123-y

Eller, J.D. 1999. From culture to ethnicity to conflict: an anthropological perspective on international ethnic conflict. Ann Arbor: University of Michigan Press. https://doi.org/10.3998/mpub.14446

Fu, Q., M. Meyer, X. Gao, U. Stenzel, H.A. Burbano, J. Kelso \& S. PӓÄвo. 2013. DNA analysis of an early modern human from Tianyuan Cave, China. Proceedings of the National Academy of Sciences of the USA 110: 2223-27. https://doi.org/10.1073/pnas.1221359110

Fu, Q., M. Hajdinjak, O.T. Moldovan, S. Constantin, S. Mallick, P. Skoglund, N. Patterson, N. Rohland, I. Lazaridis, B. Nickel, B. Viola, K. Prufer, M. Meyer, J. Kelso, D. Reich \& S. PaAbo. 2015. An early modern human from Romania with a recent Neanderthal ancestor. Nature 524: 216-19. https://doi.org/10.1038/nature14558

Gallego Llorente, M., E.R. Jones, A. Eriksson, V. Siska, K.W. Arthur, J.W. Arthur, M.C. Curtis, J.T. Stock, M. Coltorti, P. Pieruccini, S. Stretton, F. Brock, T. Higham, Y. Park, M. Hofreiter, D.G. Bradley, J. BhaK, R. Pinhasi \& A. Manica. 2015. Ancient Ethiopian genome reveals extensive Eurasian admixture in Eastern Africa. Science 350: 820-22. https://doi.org/10.1126/science.aad2879

Giblin, J., R. King \& B. Smith. 2014. Introduction: de-centring ethical assumptions by re-centring ethical debate in African archaeology. Azania: Archaeological Research in Africa 49: 131-35. https://doi.org/10.1080/0067270X.2014.904979

Hrduicka, A. 1918. Physical anthropology: its scope and aims; its history and present status in America. American Journal of Physical Anthropology 1: 133-82. 
Joseph, T. 2017. How genetics is settling the Aryan migration debate. The Hindu, 16 June 2017.

Kaestle, F.A. \& K.A. Horsburgh. 2002. Ancient DNA in anthropology: methods, applications, and ethics. American Journal of Physical Anthropology Supplement 5: 92-130. https://doi.org/10.1002/ajpa.10179

MacEachern, S. 2000. Genes, tribes, and African history. Current Anthropology 41: 357-84. https://doi.org/10.1086/300144

- 2013. Genetics and archaeology, in P. Mitchell \& P.J. Lane (ed.) The Oxford handbook of African archaeology: 65-76. Oxford: Oxford University Press.

Makarewicz, C., N. Marom \& G. Bar-Oz. 2017. Palaeobiology: ensure equal access to ancient DNA. Nature 548: 158. https://doi.org/10.1038/548158a

Matisoo-Smith, E. \& K.A. Horsburgh. 2012. DNA for archaeologists. Walnut Creek (CA): Left Coast.

Meyer, M. \& M. KirCher. 2010. Illumina sequencing library preparation for highly multiplexed target capture and sequencing. Cold Spring Harbor Protocols 2010(6): 1-10. https://doi.org/10.1101/pdb.prot5448

Meyer, M., M. Kircher, M.T. Gansauge, H. Li, F. Racimo, S. Mallick, J.G. Schraiber, F. Jay, K. Prufer, C. de Filippo, P.H. Sudmant, C. Alkan, Q. Fu, R. Do, N. Rohland, A. Tandon, M. Siebauer, R.E. Green, K. Bryc, A.W. Briggs, U. Stenzel, J. Dabney, J. Shendure, J. Kitzman, M.F. Hammer, M.V. Shunkov, A.P. Derevianko, N. Patterson, A.M. Andres, E.E. Eichler, M. Slatkin, D. Reich, J. Kelso \& S. Paabo. 2012. A high-coverage genome sequence from an archaic Denisovan individual. Science 338: 222-26. https://doi.org/10.1126/science.1224344

Mitchell, P.D. \& M. Brickley (ed.). 2017. Updated guidelines to the standards for recording human remains. Reading: Chartered Institute for Archaeologists.

Morris, A.G. 2014. Controversies about the study of human remains in post-Apartheid South Africa, in B. O’Donnabhain \& M.C. Lozada (ed.) Archaeological human remains: global perspectives: 189-98. Cham: Springer.

- 2017. Ancient DNA comes of age, but still has some teenage problems. South African Journal of Science 113(9-10): 1-2.

https://doi.org/10.17159/sajs.2017/a0232

Morris, A.G., A. Heinze, E.K.F. Chan, A.B. Smith \& V.M. Hayes. 2014. First ancient mitochondrial human genome from a prepastoralist southern African. Genome Biology and Evolution 6: 2647-53. https://doi.org/10.1093/gbe/evu202
Musonda, F.B. 2013. Decolonising the Broken Hill skull: cultural loss and a pathway to Zambian archaeological sovereignty. African Archaeological Review 30: 195-220. https://doi.org/10.1007/s10437-013-9134-3

Nienaber, W.C. \& M. Steyn. 2011. Republic of South Africa, in N. Márquez-Grant \& L. Fibiger (ed.) Physical anthropology and legislation: European perspectives and beyond: 501-12. New York: Routledge.

Nordling, L. 2017. How the genomics revolution could finally help Africa. Nature 544: 20-22. https://doi.org/10.1038/544020a

Parsons, N. \& A. Segobye. 2002. Missing persons and stolen bodies: the repatriation of 'El Negro' to Botswana, in C. Fforde, J. Hubert \& P. Turnbull (ed.) The dead and their possessions: repatriation in principle, policy and practice: 245-55. London: Routledge. https://doi.org/10.4324/9780203165775_ chapter_20

Pinhasi, R., D. Fernandes, K. Sirak, M. NovaK, S. Connell, S. Alpaslan-Roodenberg, F. Gerritsen, V. Moiseyev, A. Gromov, P. Raczky, A. Anders, M. Pietrusewsky, G. Rollefson, M. Jovanovic, H. TrinhHoang, G. Bar-Oz, M. Oxenham, H. Matsumura \& M. Hofreiter. 2015. Optimal ancient DNA yields from the inner ear part of the human petrous bone. PLoS ONE 10: e0129102. https://doi.org/10.1371/journal.pone.0129102

Pluciennik, M. 2006. Clash of cultures? Archaeology and genetics. Documenta Praehistorica 33: 39-49. https://doi.org/10.4312/dp.33.6

Pollard, AM. \& P. Bray. 2007. A bicycle made for two? The integration of scientific techniques into archaeological interpretation. Annual Review of Anthropology 36: 245-59.

Robertshaw, P. 2012. African archaeology, multidisciplinary reconstructions of Africa's recent past, and archaeology's role in future collaborative research. African Archaeological Review 29: 95-108. https://doi.org/10.1007/s10437-012-9113-0

Rodríguez-VARELA, R., T. GÜNTHER, M. KrZewiŃska, J. Stor̊̊, T.H. GillingWater, M. MacCallum, J.L. Arsuaga, K. Dobney, C. Valdiosera, M. Jakobsson, A. Götherström \& L. GirdLAND-Flink. 2017. Genomic analyses of pre-European conquest human remains from the Canary Islands reveal close affinity to modern North Africans. Current Biology 27: 3396-3402. https://doi.org/10.1016/j.cub.2017.09.059

SAnders, E.R. 1969. The Hamitic hypothesis: its origin and functions in time perspective. Journal of African History 10: 521-32. https://doi.org/10.1017/S0021853700009683 
SASI. 2017. San code of research ethics. Kimberly: South African San Institute. Available at: http://trustproject.eu/wp-content/uploads/2017/03/SanCode-of-RESEARCH-Ethics-Booklet-final.pdf (accessed 17 May 2018).

Schlebusch, C.M., H. Malmström, T. GÜNther, P. SJödin, A. Coutinho, H. Edlund, A.R. Munters, M. Vicente, M. Steyn, H. Soodyall, M. Lombard \& M. Jakobsson. 2017. Southern African ancient genomes estimate modern human divergence to 350,000 to 260,000 years ago. Science 358: 652-55.

https://doi.org/10.1126/science.aao6266

Schmidt, P.R. \& I. PikiraYi. (ed.). 2016. Community archaeology and heritage in Africa: decolonizing practice. London: Routledge.

Schuenemann, V.J., A. Peltzer, B. Welte, W.P. van Pelt, M. Molak, C.C. Wang, A. Furtwangler, C. Urban, E. Reiter, K. Nieselt, B. Tessmann, M. Francken, K. Harvati, W. HaAk, S. Schiffels \& J. Krause. 2017. Ancient Egyptian mummy genomes suggest an increase of Sub-Saharan African ancestry in post-Roman periods. Nature Communications 8: 15694. https://doi.org/10.1038/ncomms15694

Seligman, C.G. 1930. Races of Africa. London: Thornton Butterworth Ltd.

Sirak, K.A., D.M. Fernandes, O. Cheronet, M. Novak, B. Gamarra, T. Balassa, Z. Bernert, A. Cseki, J. Dani, J.Z. Gallina, G. Kocsis-Buruzs, I. Kovari, O. Laszlo, I. Pap, R. Patay, Z. Petkes, G. Szenthe, T. Szeniczey, T. Hajdu \& R. Pinhasi. 2017. A minimally invasive method for sampling human petrous bones from the cranial base for ancient DNA analysis. Biotechniques 62: 283-89. https://doi.org/10.2144/000114558

Skoglund, P., J.C. Thompson, M.E. Prendergast, A. Mittinik, K. Sirak, M. Hajdinjak, T. Salie, N. Rohland, S. Mallick, A. Peltzer, A. Heinze, I. Olalde, M. Ferry, E. Harney, M. Michel, K. Stewardson, J.I. Cerezo-Román, C. Chiumia, A. Crowther, E. Gomani-Chindebvu, A.O. Gidna, K.M. Grillo, I.T. Helenius, G. Hellenthal, R. Helm, M. Horton, S. López, A.Z.P. Mabulla, J. Parkington, C. Shipton, M.G. Thomas, R. Tibesasa, M. Welling, V.M. Hayes, D.J. Kennett, R. Ramesar, M. Meyer, S. Pääbo, N. Patterson, A.G. Morris, N. Boivin, R. Pinhasi, J. Krause $\&$ D. Reich. 2017. Reconstructing prehistoric African population structure. Cell 171: 59-71. https://doi.org/10.1016/j.cell.2017.08.049
Steyn, M., A.G. Morris, M.N. Mosothwane, W.C. Nienaber \& G.J.R. MaAt. 2013. Opening the cupboard: lessons in biology and history from African skeletons. Goodwin Series 11: 1-5.

Straight, B., P.J. Lane, C.E. Hilton \& M. Letua. 2015. 'It was maendeleo that removed them': disturbing burials and reciprocal knowledge production in a context of collaborative archaeology. Journal of the Royal Anthropological Institute 21: 391-418. https://doi.org/10.1111/1467-9655.12212

Tilley, H. 2016. Medicine, empires, and ethics in colonial Africa. AMA Journal of Ethics 18: 743-53. https://doi.org/10.1001/journalofethics.2016.18. 7.mhst1-1607

Trigger, B.G. 2006. A history of archaeological thought ( $2^{\text {nd }}$ edition). Cambridge: Cambridge University Press.

WAC (World Archaeological Congress). 1989. The Vermillion Accord on human remains. Available at: http://worldarch.org/code-of-ethics/ (accessed 17 May 2018).

Wittwer-Backofen, U., M. Kästner, D. Möller, M. Vohberger, S. Lutz-Bonengel \& D. Speck. 2014. Ambiguous provenance? Experience with provenance analysis of human remains from Namibia in the Alexander Ecker Collection. Anthropologischer Anzeiger Journal of Biological and Clinical Anthropology 71(1-2): 65-86.

Wright, G.E., P.G. Koornhof, A.A. Adeyemo \& N. Tiffin. 2013. Ethical and legal implications of whole genome and whole exome sequencing in African populations. BMC Medical Ethics 14: 21. https://doi.org/10.1186/1472-6939-14-21

Yakubu, A., P. Tindana, A. Matimba, K. Littler, N.S. Munung, E. Madden, C. Staunton \& J. De VRIES. 2018. Model framework for governance of genomic research and biobanking in Africa-a content description. AAS Open Research 1: 13. https://doi.org/10.12688/aasopenres.12844.1

Received: 1 December 2017; Revised: 27 February 2018; Accepted: 29 March 2018

(C) Antiquity Publications Ltd, 2018 